\title{
The herpesvirus 8 encoded chemokines vCCL2 (vMIP-II) and vCCL3 (vMIP-III) target the human but not the murine lymphotactin receptor Hans R Lüttichau ${ }^{1,2}$
}

Address: ${ }^{1}$ Laboratory for Molecular Pharmacology, Department of Neuroscience and Pharmacology, Panum Institute, DK-2200 Copenhagen, Denmark and ${ }^{2}$ Department for Infectious Diseases, Hvidovre Hospital Copenhagen, Denmark

Email: Hans R Lüttichau - LUTTICHAU@sund.ku.dk

Published: 21 April 2008

Virology Journal 2008, 5:50 doi:10.1186/1743-422X-5-50

This article is available from: http://www.virologyj.com/content/5/I/50

(c) 2008 Lüttichau; licensee BioMed Central Ltd.

This is an Open Access article distributed under the terms of the Creative Commons Attribution License (http://creativecommons.org/licenses/by/2.0), which permits unrestricted use, distribution, and reproduction in any medium, provided the original work is properly cited.
Received: 16 November 2007

Accepted: 21 April 2008

\begin{abstract}
Background: Large DNA-viruses such as herpesvirus and poxvirus encode proteins that target and exploit the chemokine system of their host. The Kaposi sarcoma- associated herpes virus (KSHV) encodes three chemokines. Two of these, vCCL2 and vCCL3, target the human lymphotactin receptor as an antagonist and a selective agonist, respectively. Therefore these virally endcoded chemokines have the potential to be used as tools in the study of lymphotactin receptor pathways in murine models.
\end{abstract}

Results: The activities of vCCL2, vCCL3, human lymphotactin $(X C L I)$ and murine lymphotactin $(\mathrm{mXCLI})$ were probed in parallel on the human and murine lymphotactin receptor (XCRI and $\mathrm{mXCRI}$ ) using a phosphatidyl-inositol assay. On the human XCRI, vCCL3, $\mathrm{mXCLI}$ and XCLI acted as agonists. In contrast, only $\mathrm{mXCLI}$ was able to activate the murine lymphotactin receptor. Using the same assay, vCCL2 was able to block the response using any of the three agonists on the humane lymphotactin receptor with $\mathrm{IC}_{50} \mathrm{~s}$ of 2-3 nM. However, vCCL2 was unable to block the response of $\mathrm{mXCLI}$ through the murine lymphotactin receptor.

Conclusion: This study shows that vCCL2 and vCCL3 cannot be used to investigate lymphotactin receptor pathways in murine models. These results also add vCCL2 and vCCL3 to a growing list of viral chemokines with known human chemokine receptor targets, which do not target the corresponding murine receptors. This fits with the observation that viral and endogenous ligands for the same human chemokine receptor tend to have relatively divergent amino-acid sequences, suggesting that these viruses have fine-tuned the design of their chemokines such that the action of the viral encoded chemokines cannot be expected to cross species barriers.

\section{Background}

During the last 15 years, more than 40 chemokines have been identified in the human genome and nearly all have been characterized pharmacologically as agonists and led to the identification of 18 signaling 7TM chemokine receptors $[1,2]$.
Chemokines are 70-80 amino acid proteins with a characteric three-dimensional fold, which are involved in guiding and activating distinct leukocyte subsets. Chemokines can be divided into four sub-families on the basis of the pattern and number of the conserved cysteine residues located near their $\mathrm{N}$-terminus, which are involved in 
disulfide binding formation; the CC-, $\mathrm{CXC}_{-}, \mathrm{CX}_{3} \mathrm{C}$ and $\mathrm{XC}$ family, respectively. The XC-chemokines have only one cysteine in the $\mathrm{N}$-terminus. Chemokines act through 7TM GPCRs of which we today know ten CC-chemokine receptors (CCR1-10), six CXC-receptors (CXCR1-6), one CX ${ }_{3} \mathrm{C}-$ receptor $\left(\mathrm{CX}_{3} \mathrm{CR} 1\right)$ and one $\mathrm{XC}$-receptor (XCR1). The role played by the lymphotactin receptor (XCR1) in the immune system is poorly understood.

In the same period, seven chemokines encoded by large human DNA viruses have been found by genomic sequence analysis. Most of these have been characterized and have been found to have different pharmacological phenotypes as some target multiple receptors, some only one receptor, some act as agonists, while others act as antagonists [3-11](Table 1).

Obviously viral encoded chemokines are important in the study of viral pathogenesis, but they can also be used as tools in the investigation of specific chemokine receptors. Blocking of chemokine receptor action is important in several assays and immunological models studying the chemokine system. One example is the selective CCR8 antagonist MC148 encoded by the Molluscuum Contagiosum Virus [7]. Another example is the broad-spectrum chemokine antagonist vCCL2 encoded by HHV8, which blocks a number of chemokine receptors such as CCR1, CCR2, CCR5, CX3CR1, CXCR4 and the lymphotactin receptor XCR1 $[6,7]$. Thus vCCL2 has been shown to reduce the inflammatory response in small animal models models [12-15]. However, viral-encoded agonists are also useful in the investigation of the role of a chemokine receptor even when the endogenous human ligand has been identified, because they can have greater potency and be more stable than their human counterparts. This is the case for another HHV8 encoded chemokine vCCL3, which was recently found to have a 10-fold higher potency than lymphotactin on the human lymphotactin receptor [10].

Thus HHV8 encodes both the only known high-affinty lymphotactin receptor antagonist, vCCL2, as well as the most potent agonist, vCCL3, known to XCR1 (Figure 1). Therefore both vCCL2 and vCCL3 are valuable tools in evaluating the role of the lymphotactin receptor. However, when using animal models it is obviously important to characterize these proteins on the specific animal chemokine receptors. Here we report the characterization of the viral-encoded proteins vCCL2 and vCCL3 on the murine lymphotactin receptor done in parallel with the humane XCR1.

\section{Results and discussion}

Recently, we reported that the HHV8 encoded chemokine vCCL3 is a selective agonist of the human lymphotactin receptor XCR1, while vCCL2, encoded by the same virus, acts as an antagonist on this same receptor [10].

\section{Agonistic activity on XCRI and $m X C R I$}

In order to determine whether these two chemokines encoded by a human virus and acting on a human receptor also were able to target the corresponding murine receptor we performed phosphatidyl-inositol assays using a promiscuous chimeric G-protein[16] co-transfected with either the human XCR1 gene inserted in the pcDNA3.1 vector or the murine XCR1 gene inserted into the pTEJ vector. As expected, XCL1, mXCL1 and vCCL3 activated the human lymphotactin receptor in a dose responsive manner (Figure 2). As reported earlier [10], the potency of vCCL3 $\left(\mathrm{EC}_{50}=3.7 \mathrm{nM}\right)$ was nearly 10 -fold

Table I: Chemokines encoded by human viruses and their human and murine chemokine receptor targets.

\begin{tabular}{|c|c|c|c|c|c|c|}
\hline Virus & Gene & Protein & human chemokine receptor targets & Ref & $\begin{array}{l}\text { also targeting the corresponding } \\
\text { murine chemokine receptor }\end{array}$ & Ref \\
\hline \multirow[t]{2}{*}{ CMV } & ULI46 & vCXCLI & Selective CXCR2 agonist & 11 & No & 20 \\
\hline & ULI47 & vCXCL2 & $?$ & & & \\
\hline HHV6a & U83B & vCCL4 & Selective CCR2 agonist & 9 & $?$ & \\
\hline \multirow[t]{10}{*}{ HHV8 } & K6 & vCCLI (vMIP-I) & Selective CCR8 agonist & $3,5,10$ & Yes & 18 \\
\hline & K4 & vCCL2 (vMIP-II) & $\begin{array}{c}\text { Broadspectrum chemokine receptor } \\
\text { antagonist }\end{array}$ & & & \\
\hline & & & CCRI & 6,7 & Yes & 19 \\
\hline & & & CCR2 & 6,7 & Yes & 19 \\
\hline & & & CCR5 & 6,7 & Yes & 19 \\
\hline & & & XCRI & 7 & No & This paper \\
\hline & & & CX3CRI & 7 & $?$ & \\
\hline & & & CXCR4 & 6,7 & $?$ & \\
\hline & & & CCR3 agonist & 17 & $?$ & \\
\hline & K4.I & vCCL3 (vMIP-III) & Selective XCRI agonist & 10 & No & This paper \\
\hline MCV & $\mathrm{MCI} 48$ & $\mathrm{MCC}$ & Selective CCR8 antagonist & 7 & No & 18 \\
\hline
\end{tabular}

aThe protein product from the U83 gene of HHV6A has not been included as its signal sequence include a premature stop codon. 


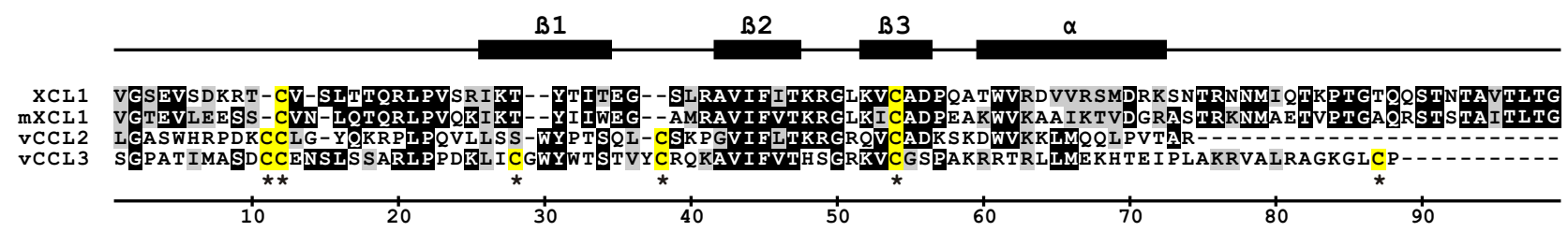

Figure I

Alignment of human, murine and viral ligands for the human and the murine lymphotactin receptor. The upper panel shows the primary structure of the two HHV8 encoded chemokines, vCCL2, vCCL3, the human lymphotactin XCLI and the murine lymphotactin $\mathrm{mXCLI}$ aligned using CLUSTALW from Kyoto University Bioinformatics Center. Identical amino acids are shown in white on black, whereas similar amino acids are shown in black on light grey. Cysteines are shown in black on yellow and presumed disulfide bridges are marked with an asterisk. Likely O-glycosylation sites using the CBS prediction server are marked white on blue. The secondary structure of XCLI as determined by NMR is indicated by the line above the alignment [2I].

greater than the potency of XCL1 $\left(\mathrm{EC}_{50}=30 \mathrm{nM}\right.$, assuming Emax equal to that of vCCL3) on the human XCR1 receptor. Interestingly, murine lymphotactin had a 3 -fold higher potency $\left(E^{50}=11 \mathrm{nM}\right)$ than human lymphotactin on the human lymphotactin receptor.

In contrast, only mXCL1 was able to activate the murine lymphotactin receptor, while vCCL3 and XCL1 were unable to do so (Figure 2). It should be noted that only a relatively high concentration of mXCL1 (100 nM) consistently generated an IP3 response through the murine lymphotactin receptor. This observation could be explained if mXCL1 was not properly folded or was partly proteolyzed. However, this is unlikely as $1 \mathrm{nM}$ of mXCL1 in all assays was able to activate the human lymphotactin receptor. To rule out a vector-specific effect, we performed similar assays using the mXCR1 gene inserted into pcDNA3.1. However, no difference in results was found using the two vector constructs (data not shown). The low potency of mXCL1 on the mXCR1 in the IP3 assay could also be related to the cell-line used, but again this explanation seems unlikely as we also had difficulties in generating calcium mobilization responses to mXCL1 in single clones of L1.2- and 300.19- cells transfected with murine lymphotactin receptor cDNA, which suggested that mXCL1 indeed had low potency for the lymphotactin receptor. A more likely explanation of the poor potency of mXCL1 for mXCR1 could be that either the extra N-terminal methionine or the lack of glycosylation of the E. Coliproduced recombinant murine lymphotactin prevented proper activation of the murine but not the human lymphotactin receptor.

\section{Antagonistic activity on XCRI and $\mathrm{mXCRI}$}

We next tested whether vCCL2 was able to act as an antagonist on the murine and the human lymphotactin receptors. As reported before [10], vCCL2 did block responses through XCR1 using submaximal doses of either XCL1, mXCL1 or vCCL3 (Figure 3 ). As expected the $\mathrm{IC}_{50}$ values were almost the same no matter which agonist was used ( $\mathrm{mXCL} 1$ had an $\mathrm{IC}_{50}=2.1 \mathrm{nM}$; XCL1 had an $\mathrm{IC}_{50}=3.0 \mathrm{nM}$ and vCCL3 had an $\mathrm{IC}_{50}=2.8 \mathrm{nM}$ ). In contrast, vCCL2 was unable to inhibit the response of mXCL1 through the murine lymphotactin receptor (Figure 3).

\section{Virally encoded chemokines and species barriers}

Surprisingly, XCL1 could not activate the murine lymphotactin receptor although the sequences of mXCL1 and XCL1 are very similar (60\% identity and $84 \%$ similarity using BLASTP 2.2.17 at the NCBI website)(Figure 1). In contrast, vCCL2 and vCCL3 have only 31 and $32 \%$ identity and 50 and $54 \%$ similarity to XCL1, although all three ligands target the same receptor. These points are illustrated on the left side of Figure 4. XCL1 and mXCL1 are clustered, whereas vCCL2 and vCCL3 are more distantly related to XCL1 although they target the same receptor (right side of Figure 4). As can be seen from Figure 4, it seems to be a rule that human encoded chemokines acting on a particular chemokine receptor, cluster with each other but not with the viral encoded chemokines targeting the same receptor. There is one exception, vCCL2, which on the dendrogram in Figure 4 lies in the middle of a cluster of CCR1, CCR2, and CCR5 ligands. However, vCCL2 also targets XCR1, CX3CR1 and CXCR4 and it does not cluster with the ligands of these receptors.

This sequence divergence between viral and human chemokines may explain why human and not viral encoded chemokines in general are able to cross a species barrier. Human encoded chemokines are very similar to their murine counterparts but very dissimilar to the viral encoded chemokines they share receptor targets with. Thus one can imagine that a virus during evolution has picked up an ancestral chemokine gene and optimized it 

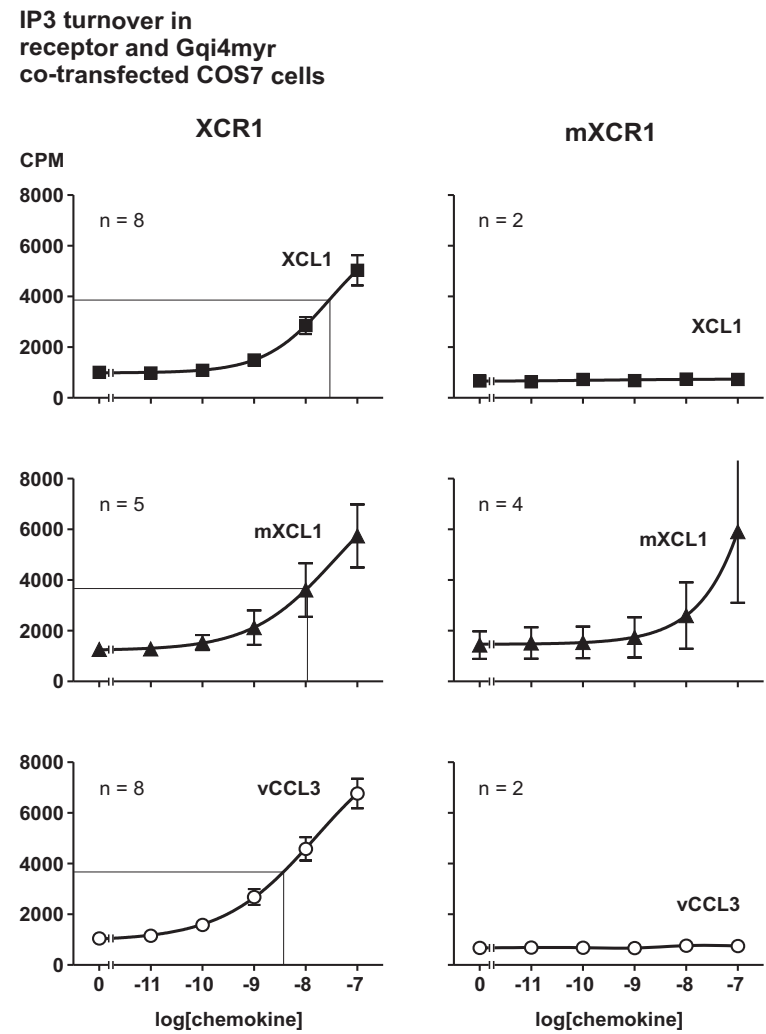

Figure 2

Activation of the human and murine lymphotactin receptor by human, murine and viral agonists. Doseresponse experiments measuring $\mathrm{IP}_{3}$ turnover in COS-7 cells transiently transfected with the human and murine lymphotactin receptors $X C R I$ and $m X C R I$ and the promiscuous chimeric G-protein Gqi4myr using increasing concentrations of the agonists XCLI (black square), $\mathrm{mXCLI}$ (black triangle) and $v C C L 3$ (white circle). The thin line indicate the $\mathrm{EC}_{50}$ for the particular ligand (assuming Emax equal to that of $v C C L 3$ ). All assays were performed in duplicate.

in a unique way to suit the virus, while retaining the ability to target the corresponding chemokine receptor of its host. However, during this process the hijacked chemokine has changed so much that it has lost the ability to cross species barriers. As seen in Table 1, the CMV encoded chemokine vCXCL1, the pox virus encoded chemokine MC148 and, as shown in this paper, the KSHV encoded chemokines vCCL2 and vCCL3 are not able to target their corresponding murine receptors, while only vCCL1 encoded by KSHV has retained this ability [3,57,10,11,17-20].

vCCL2 has been used in several in vivo models, especially in rodent models, as a broad-spectrum chemokine receptor blocker. For example vCCL2 has been shown to reduce
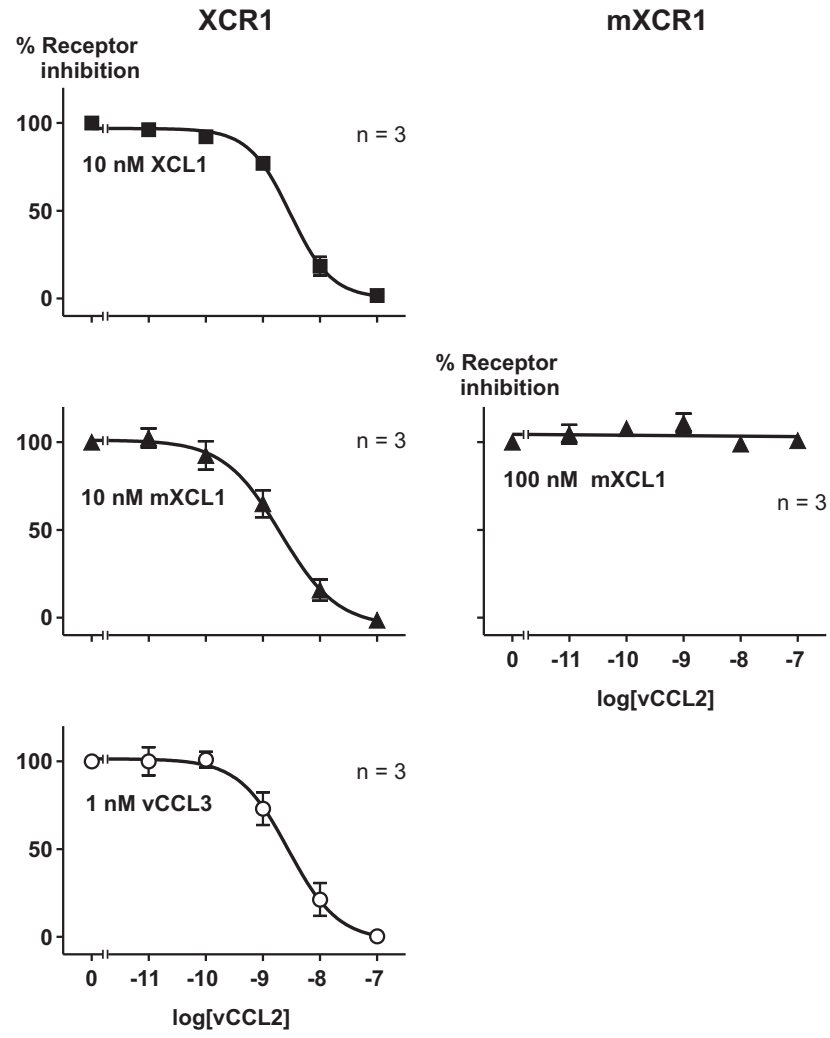

Figure 3

Inhibition of the human and murine lymphotactin receptor by the viral antagonist vCCL2. Dose-response experiments for inhibition of $\mathrm{IP}_{3}$-turnover by the antagonist vCCL2 induced by XCLI (black square) mXCLI (black triangle) and vCCL3 (white circle) in COS-7 cells transiently transfected with the human and murine lymphotactin receptors XCRI and $\mathrm{mXCRI}$ and the promiscuous chimeric Gprotein Gqi4myr. All assays were performed in duplicate.

T-cell mediated inflammation in a murine lymphocytic choriomeningitis model [14], to protect the brain of mice against cerebral ischemia [15], to reduce inflammation in a rat model of spinal cord contusion [13] and in a rat model of glomerulonephritis [12]. The results from this study suggest that the reduction of inflammation by vCCL2 in these experiments is not due to inhibition of the lymphotactin receptor, but must be due to inhibition of one or more of the CCR1, CCR2, CCR5, CX3CR1 and CXCR4 receptors.

\section{Conclusion}

The chemokines vCCL2 and vCCL3 encoded by KSHV do not target the murine lymphotactin receptor, although they act as a high potency antagonist and agonist respectively, on the human lymphotactin receptor. So the only tool left, for investigating the role of the lymphotactin receptor pathways in murine models, is the commercially 


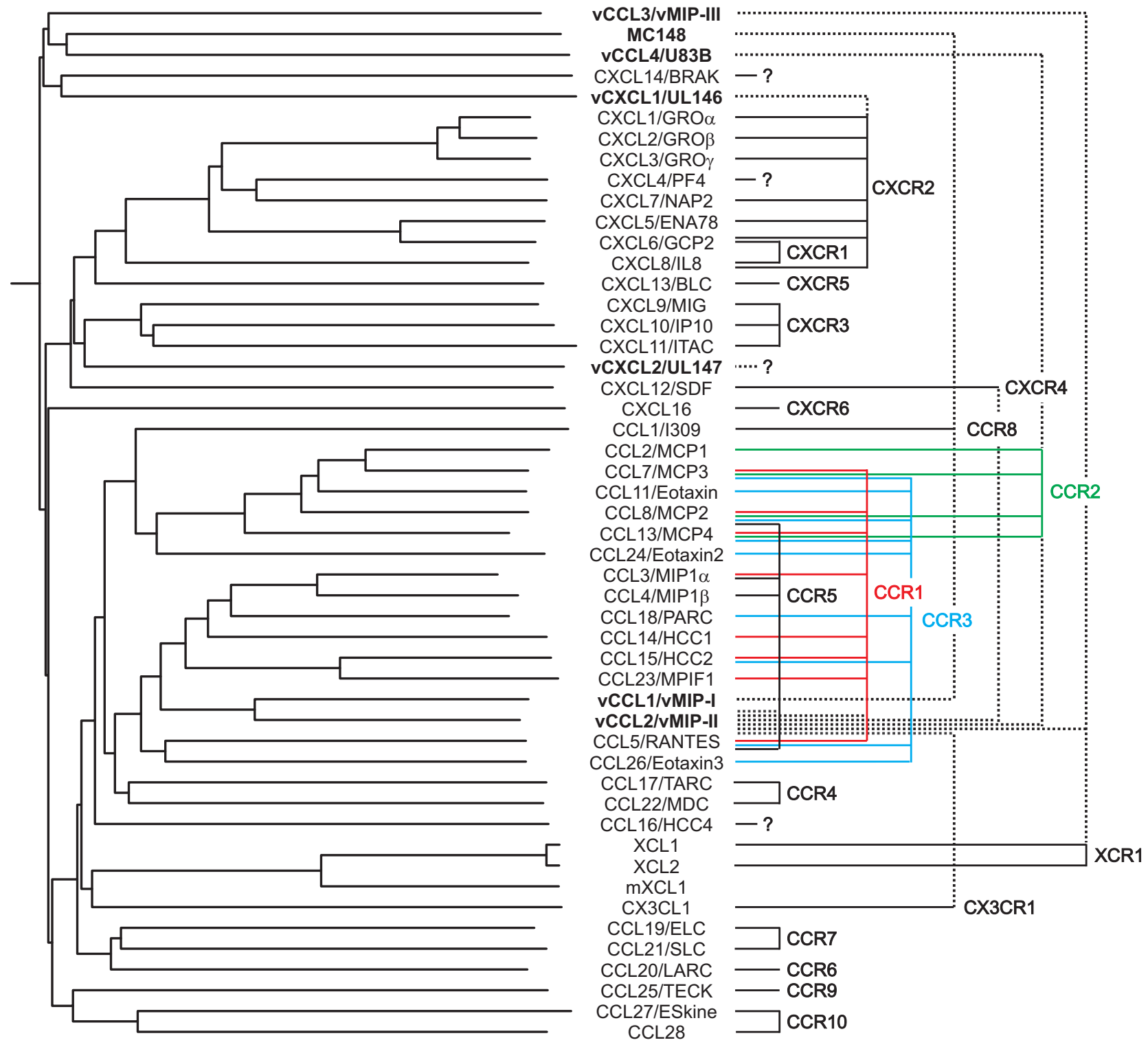

\section{Figure 4}

Amino-acid sequence similarity of human and viral encoded chemokines compared to their chemokine receptor targets. Left side of the figure is a comparison of the similiarity of the primary protein sequence of human and virally encoded chemokines (using ClustalW I.83 and an unbranched dendrogram) with the receptor targets of the specific chemokines seen on the right side of the figure. The names of the virally encoded chemokines are highlighted in bold. On the right hand side a line is used to illustrate that a specific chemokine is a ligand for a specific chemokine receptor. The line is unbroken for endogenous human chemokines and dotted for virally encoded chemokines. The murine lymphotactin has been included to illustrate the great similarity between XCLI and $\mathrm{mXCLI}$.

available recombinant form of murine lymphotactin with a rather low potency on the mXCR1 receptor. Furthermore, when the findings of this paper are combined with the results from other studies on the ability of chemokines encoded by human viruses to target the murine counter- parts to their human chemokine receptor targets, it can be concluded that they rarely do so. In contrast, human encoded chemokines in general are able to cross the species barrier and target their corresponding murine chemokine receptors. 


\section{Methods \\ Chemokines}

mXCL1, XCL1, vCCL2 were purchased from R\&D (Minneapolis, MN). Recombinant vCCL3 (GenBank accession number U93872) was produced as described previously [10], briefly cell media collected from COS7 cells transfected with the K4.1 gene from HHV8 was collected and purified on a cation-exchange column followed by reverse phase HPLC. The elution position of the recombinant vCCL3 protein as well as the purity was identified with mass-spectroscopy and $\mathrm{NH}_{2}$-terminal sequence analysis on an ABI 494 protein sequencer (Perkin-Elmer, CA).

\section{Cloning of $m X C R I$}

The mXCR1 gene was amplified by PCR from a murine cDNA library and inserted into the pcDNA3.1 vector and the pTEJ8 vector. Start- and end-primers were designed from the GenBank accession number NM 011798. Nucleotide sequence analysis was performed on an ABI 310 sequence system (Perkin-Elmer, CA) in-house or by MWG Biotech (Ebersberg, Germany). The human XCR1 gene inserted in the pcDNA3.1 vector was purchased from the UMR cDNA Resource Center (Rolla, MO).

\section{Stable cell lines}

mXCR1 in pTej was transfected into the murine pre-B cell line L1.2 and hXCR1 in pcDNA 3.1 was transfected into the murine pre-B cell line 300.19. Stable transfectants were obtained after limiting dilution and chemical selection with G418 and functional clones were selected based upon their calcium responses to mXCL1 and XCL1, respectively.

\section{Phosphatidyl-inositol assay}

COS-7 cells were transiently transfected by a calcium phosphate precipitate method with addition of chloroquine. Briefly, $2 \times 10^{6} \mathrm{COS}-7$ cells were transfected with $30 \mathrm{ug}$ of cDNA encoding the promiscuous chimeric G-

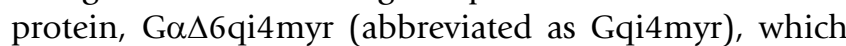
allows the Gai-coupled receptor to couple to the Gaq pathway (phospholipase $\mathrm{C}$ activation measured as PIturnover) [16], with or without $20 \mathrm{ug}$ receptor (mXCR1 or XCR1) cDNA. After transfection, COS-7 cells $\left(2.5 \times 10^{4}\right.$ cells/well) were incubated for 24 hours with $2 \mu \mathrm{Ci}$ of ${ }^{3} \mathrm{H}$ $m y o$-inositol in $0.4 \mathrm{ml}$ growth medium per well in 24multiwells tissue culture plates. Cells were washed twice in $20 \mathrm{mM}$ Hepes, pH 7.4, supplemented with $140 \mathrm{mM}$ $\mathrm{NaCl}, 5 \mathrm{mM} \mathrm{KCl}, 1 \mathrm{mM} \mathrm{MgSO}{ }_{4}, 1 \mathrm{mM} \mathrm{CaCl}_{2}, 10 \mathrm{mM}$ glucose and $0.05 \%(\mathrm{w} / \mathrm{v})$ bovine serum albumin and were incubated in $0.4 \mathrm{ml}$ of the same buffer supplemented with $10 \mathrm{mM} \mathrm{LiCl}$ at $37^{\circ} \mathrm{C}$ for 15 minutes. The ligands were subsequently added and incubated for $90 \mathrm{~min}$. In the antagonist assay vCCL2 was added $10 \mathrm{~min}$ before the agonist to ensure proper interaction of the receptors with vCCL2. Cells were extracted by addition of $1 \mathrm{ml} 10 \mathrm{mM}$ Formic acid to each well followed by incubation on ice for 30-60 min. The generated $\left[{ }^{3} \mathrm{H}\right]$-inositol phosphates were purified on AG1-X8 anion-exchange resin (Bio-Rad Laboratories, Hercules, $\mathrm{CA}$ ). Determinations were made in duplicate.

\section{Calcium mobilization experiments}

L1.2 cells stably transfected with mXCR1 were loaded with Fura-2AM (Molecular Probes, Eugene, OR) in RPMI with 1\% FCS for 20-30 $\mathrm{min}$. and washed in the same buffer. Aliqouts were made of $1 \times 10^{6}$ cells, each aliqout was pelleted and resuspended in 500 ul PBS 1\% FCS with $10 \mathrm{mM}$ EGTA. Flourescence was measured on a Jobin Yvon FlouroMax-2 (Jobin Yvon Spex, Cedex, France) as the ratio of emission at $490 \mathrm{~nm}$ when excited at $340 \mathrm{~nm}$ and $380 \mathrm{~nm}$ respectively.

\section{Abbreviations}

KSHV, Kaposi sarcoma-associated herpes virus; GPCR, Gprotein-coupled receptor; HHV8, human herpesvirus 8; IP3, inositol-tri-phosphate; vMIP, viral macrophage inflammatory protein; XCL, lymphotactin; XCR1 lymphotactin receptor; 7TM, 7 transmembrane.

\section{Competing interests}

The author declares that they have no competing interests.

\section{Authors' contributions}

HRL is responsible for all aspects of this article.

\section{Acknowledgements}

I thank Kirsten Culmsee for excellent technical assistance.

This study was supported by the by grants from the Foundation of A.P.Møller and Chastine Mc-Kinney Møller, the Foundation of Arvid Nilsson, the Augustinus Foundation, the Beckett-Foundation, the Foundation of Bent Bøgh and wife, the Foundation of Carl and Ellen Hertz, the Foundation of Christian Larsen and Ellen Larsen, the Foundation of Frode V. Nyegaard and wife, the Foundation of E. Danielsen and wife, the Foundation of Einar Hansen and wife, the Foundation of Michael Hermann Nielsen, the Foundation of Else and Mogens Wedell-Wedellsborg, the Foundation of Karl G Andersen, the Harboe-Foundation, the Illum-Foundation, the Foundation of Johan Boserup and Lise Boserup, the Foundation of Niels Hansen and wife, the Foundation of Werner Richter and wife, the Foundation of Ove William Buhl Olesen and wife, the Foundation of Meta and Håkon Bagger and the Foundation of Jakob Madsen and wife.

\section{References}

I. Murphy PM, Baggiolini M, Charo IF, Hebert CA, Horuk R, Matsushima $\mathrm{K}$, Miller LH, Oppenheim JJ, Power CA: International union of pharmacology. XXII. Nomenclature for chemokine receptors. Pharmacol Rev 2000, 52:145-176.

2. Rollins BJ: Chemokines. Blood 1997, 90:909-928.

3. Dairaghi DJ, Fan RA, McMaster BE, Hanley MR, Schall TJ: HHV8encoded VMIP-I selectively engages chemokine receptor CCR8. Agonist and antagonist profiles of viral chemokines. J Biol Chem 1999, 274:21569-2I 574.

4. Dewin DR, Catusse J, Gompels UA: Identification and characterization of U83A viral chemokine, a broad and potent betachemokine agonist for human CCRs with unique selectivity and inhibition by spliced isoform. J Immunol 2006, 176:544-556. 
5. Endres MJ, Garlisi CG, Xiao H, Shan L, Hedrick JA: The Kaposi's sarcoma-related herpesvirus (KSHV)-encoded chemokine VMIP-I is a specific agonist for the CC chemokine receptor (CCR)8. J Exp Med 1999, 189:1993-1998.

6. Kledal TN, Rosenkilde MM, Coulin F, Simmons G, Johnsen AH, Alouani S, Power CA, Luttichau HR, Gerstoft J. Clapham PR, ClarkLewis I, Wells TN, Schwartz TW: A broad-spectrum chemokine antagonist encoded by Kaposi's sarcoma-associated herpesvirus. Science 1997, 277:1656-1659.

7. Luttichau HR, Stine J, Boesen TP, Johnsen AH, Chantry D, Gerstoft J, Schwartz TW: A highly selective CC chemokine receptor (CCR)8 antagonist encoded by the poxvirus molluscum contagiosum. J Exp Med 2000, 191:171-180.

8. Luttichau HR, Lewis IC, Gerstoft J, Schwartz TW: The herpesvirus 8-encoded chemokine vMIP-II, but not the poxvirus-encoded chemokine MCI48, inhibits the CCRIO receptor. Eur J Immunol 200I, 3I:I2I I-I220.

9. Luttichau HR, Clark-Lewis I, Jensen PO, Moser C, Gerstoft J, Schwartz TW: A highly selective CCR2 chemokine agonist encoded by human herpesvirus 6. I Biol Chem 2003, 278: 10928-10933.

10. Luttichau HR, Johnsen AH, Jurlander J, Rosenkilde MM, Schwartz TW: Kaposi sarcoma-associated herpes virus targets the lymphotactin receptor with both a broad spectrum antagonist vCCL2 and a highly selective and potent agonist vCCL3. J Biol Chem 2007, 282: 17794-I7805.

II. Penfold ME, Dairaghi DJ, Duke GM, Saederup N, Mocarski ES, Kemble GW, Schall TJ: Cytomegalovirus encodes a potent alpha chemokine. Proc Natl Acad Sci USA 1999, 96:9839-9844.

12. Chen S, Bacon KB, Li L, Garcia GE, Xia Y, Lo D, Thompson DA, Siani MA, Yamamoto $T$, Harrison JK, Feng L: In vivo inhibition of CC and $\mathrm{CX} 3 \mathrm{C}$ chemokine-induced leukocyte infiltration and attenuation of glomerulonephritis in Wistar-Kyoto (WKY) rats by vMIP-II. J Exp Med 1998, 188:193-198.

13. Ghirnikar RS, Lee YL, Eng LF: Chemokine antagonist infusion attenuates cellular infiltration following spinal cord contusion injury in rat. J Neurosci Res 2000, 59:63-73.

14. Lindow M, Nansen A, Bartholdy C, Stryhn A, Hansen NJ, Boesen TP, Wells TN, Schwartz TW, Thomsen AR: The virus-encoded chemokine vMIP-II inhibits virus-induced Tcl-driven inflammation. J Virol 2003, 77:7393-7400.

15. Takami S, Minami M, Nagata I, Namura S, Satoh M: Chemokine receptor antagonist peptide, viral MIP-II, protects the brain against focal cerebral ischemia in mice. J Cereb Blood Flow Metab 200I, 2I:1430-I435

16. Kostenis E: Is Galpha I 6 the optimal tool for fishing ligands of orphan G-protein-coupled receptors? Trends Pharmacol Sci 200I, 22:560-564.

17. Boshoff C, Endo Y, Collins PD, Takeuchi Y, Reeves JD, Schweickart VL, Siani MA, Sasaki T, Williams T], Gray PW, Moore PS, Chang Y, Weiss RA: Angiogenic and HIV-inhibitory functions of KSHVencoded chemokines. Science 1997, 278:290-294.

18. Luttichau HR, Gerstoft J, Schwartz TW: MCI48 encoded by human molluscum contagiosum poxvirus is an antagonist for human but not murine CCR8. J Leukoc Biol 200I, 70:277-282.

19. Rubant S, Ludwig RJ, Pfeffer J, Schulze-Johann P, Kaufmann R, Pfeilschifter JM, Boehncke WH, Radeke HH: Eukaryotic expression of the broad-spectrum chemokine receptor antagonist vMIP-II and its effects on T-cell function in vitro and in vivo. Exp Dermatol 2006, 15:634-642.

20. Sparer TE, Gosling J, Schall TJ, Mocarski ES: Expression of human CXCR2 in murine neutrophils as a model for assessing cytomegalovirus chemokine vCXCL-I function in vivo. J Interferon Cytokine Res 2004, 24:6 I I-620.

21. Kuloglu ES, McCaslin DR, Kitabwalla M, Pauza CD, Markley JL, Volkman BF: Monomeric solution structure of the prototypical ' $C$ chemokine lymphotactin. Biochemistry 200I, 40: I 2486- 12496.
Publish with Biomed Central and every scientist can read your work free of charge

"BioMed Central will be the most significant development for disseminating the results of biomedical research in our lifetime. "

Sir Paul Nurse, Cancer Research UK

Your research papers will be:

- available free of charge to the entire biomedical community

- peer reviewed and published immediately upon acceptance

- cited in PubMed and archived on PubMed Central

- yours - you keep the copyright

Submit your manuscript here:

http://www.biomedcentral.com/info/publishing_adv.asp
BioMedcentral 